\title{
Influence of Salt Concentration on Histamine Formation in Fermented Tuna Viscera (Dayok)
}

\author{
Jesebel R. Besas ${ }^{1 *}$, Erlinda I. Dizon ${ }^{2}$ \\ ${ }^{1}$ Department of Fisheries and Marine Science, College of Fisheries and Marine Science, Southern Philippines Agribusiness and Ma- \\ rine and Aquatic School of Technology, Malita, Philippines; ${ }^{2}$ Institute of Food Science and Technology, College of Agriculture, \\ University of the Philippine Los Banos, Laguna, Philippines. \\ Email: ${ }^{*}$ jillbesas@yahoo.com
}

Received September $22^{\text {nd }}, 2011$; revised November $11^{\text {th }}$, 2011; accepted November $18^{\text {th }}, 2011$

\begin{abstract}
The formation of histamine in fermented tuna (Thunnus albacares) viscera (dayok) at different salt concentrations (10\%, $17.5 \%$ and $25 \%$ ) for 7 days at ambient temperature was investigated. Effect on chemical and microbiological changes on tuna viscera were monitored. Results demonstrated that the levels of $\mathrm{pH}$, lactic acid, amino nitrogen and total volatile base nitrogen (TVB-N) increased as time of dayok fermentation progressed. The total plate count and lactic acid bacteria count decreased with increasing salt concentration. Histamine levels decreased during fermentation as salt concentration increased. Histamine levels above FDA standard limit of $50 \mathrm{ppm}$ are formed at low salt concentration (10\%) with a total plate count of $10^{7} \mathrm{cfu} / \mathrm{g}$. Results revealed that application of salt concentration greater than $17 \%$ can minimize the formation of histamine.
\end{abstract}

Keywords: Histamine; Tuna Viscera; Fermentation

\section{Introduction}

Dayok, an indigenous fermented food, is a popular native bagoong (fish paste) in Mindanao areas in the Philippines and is widely consumed as a condiment/sauce. Fish fermentation as a preservation technique has been found to contain high contents of histamine such as in fish paste and fish sauce [1]. Histamine (or scombroid) fish poisoning is a foodborne chemical intoxication caused by eating spoiled or bacterially contaminated fish [2]. Ingestion of food containing small amount of histamine when taken in large amounts ( $>50 \mathrm{mg} / 100 \mathrm{~g})$ can cause scombroid fish poisoning [3] and tuna species are most often implicated with histamine poisoning due to its high levels of histidine which is a precursor for histamine formation [4]. Histamine is formed from the action of microbial histidine decarboxylase on histidine in fish by spoilage bacteria [1].

To this effect, several studies have been conducted on fermented fishery products regarding its safety and quality parameters, e.g. studies on histamine and other biogenic amines [1,5-9]. However, only limited information is available on the use of tuna viscera in fish paste processing. Fermentation process provides suitable conditions conducive to the production of histamine due to the presence of bacterial enzyme histidine decarboxylase and free

${ }^{*}$ Corresponding author. amino acid histidine coupled with favorable environmental growth conditions on histamine forming bacteria.

The purpose of this study was to monitor the microbiological and biochemical changes of tuna viscera during fermentation and to investigate the factors influencing histamine formation in dayok fermentation.

\section{Materials and Methods}

\subsection{Tuna Viscera (Dayok) Preparation}

Yellowfin tuna (Thunnus albacares) viscera excluding the bile sac and heart was used in the study. Fresh tuna viscera were obtained from eviscerated yellowfin tuna and placed in an ice box with a fish to ice ratio of 1:2 (w/w) and were transported to the laboratory. Upon arrival, the tuna viscera was washed, drained and mixed with varying salt concentrations $(10 \%, 17.5 \%$ and $25 \%)$. The salted samples were placed in sterilized sealed bottles and were allowed to ferment for 7 days at ambient temperature. Samples for chemical and biochemical analysis were blended, then heated to $95^{\circ} \mathrm{C}$ for 5 minutes and cooled to room temperature before analysis. Simultaneous microbial and chemical analyses were conducted.

\subsection{Microbiological Analysis}

Dayok samples (5 g) were transferred aseptically and 
were homogenized in $45 \mathrm{ml}$ of sterilized peptone $(0.5 \%$ peptone) saline solution (depending on the initial salt concentration of the sample). The homogenates were serially diluted in the same diluent. One $\mathrm{ml}(1 \mathrm{ml})$ of the appropriate dilution were pipetted out and poured in Petri dishes with molten plate count agar (PCA) containing initial salt concentration of the sample for total viable count and MRS agar medium $+1 \% \mathrm{CaCO}_{3}$, for lactic acid bacteria (LAB) count. Total bacterial colonies was counted on PCA plates while colonies on MRS agar $+1 \% \mathrm{CaCO}_{3}$ showing clearing around the colonies was counted as $\mathrm{LAB}$ after the incubation period at $30^{\circ} \mathrm{C}$ for 48 hours. The bacterial count of the fermented product was expressed as $\log _{10}$ colony forming units (CFU)/g.

\subsection{Chemical Analysis}

\subsubsection{Determination of $\mathbf{P H}$}

The $\mathrm{pH}$ of homogenized tuna viscera samples were measured using a $\mathrm{pH}$ pen. The $\mathrm{pH}$ pen was calibrated with $\mathrm{pH} 4.0$ and $\mathrm{pH} 7.0$ standard buffers prior to its use.

\subsubsection{Determination of Salt Content}

Samples $(5 \mathrm{~g})$ were diluted with $100 \mathrm{ml}$ of distilled water. Five (5) $\mathrm{ml}$ of the solution was placed in a $125 \mathrm{ml}$ Erlenmeyer flask then $1 \mathrm{ml}$ of $2 \%$ potassium chromate solution was added on it. The solution was titrated with 1/50 $\mathrm{N}$ silver nitrate solution to a light orange endpoint. The percentage of salt was then calculated using the formula:

$$
\operatorname{NaCl}(\%)=\mathrm{A} \times 0.00117 \times \mathrm{F} \times \mathrm{C} \times \mathrm{DF}
$$

where $\mathrm{A}=$ titration value, $\mathrm{F}=$ factor of $1 / 50$ silver nitrate, $\mathrm{C}=$ correction constant and $\mathrm{DF}=$ dilution factor .

\subsubsection{Determination of Total Titratable Acidity (Expressed as Percent Lactic Acid)}

Five (5) $\mathrm{mL}$ of blended fish paste sample was diluted with $100 \mathrm{~mL}$ distilled water. Twenty-five (25) $\mathrm{mL}$ of the solution was placed in a $125 \mathrm{~mL}$ Erlenmeyer flask and titrated against a standardized $0.1 \mathrm{~N} \mathrm{NaOH}$ to $\mathrm{pH}$ 8.2. Percent lactic acid was then computed as follows:

$$
\text { Lactic Acid }(\%)=\frac{\mathrm{mL} \mathrm{NaOH} \times \mathrm{N}_{\mathrm{NaOH}} \times 0.09 \times 100}{\text { Volume of sample }(\mathrm{mL}) \times \mathrm{DF}}
$$

\subsubsection{Determination of Amino Nitrogen Content}

Amino nitrogen contents were determined by the Formol titration method. The sample used in determining the total titratable acidity which was previously neutralized with $0.1 \mathrm{~N} \mathrm{NaOH}$ solution to $\mathrm{pH} 8.2$ was used. The sample was added with $10 \mathrm{~mL}$ of neutralized formaldehyde $(38 \%, v / v)$. (Note that for protein-rich samples, the $\mathrm{pH}$ of the sample is expected to decreased upon addition of formaldehyde). The mixture was titrated with standard 0.1 $\mathrm{N} \mathrm{NaOH}$ to $\mathrm{pH}$ 8.2. Amino nitrogen was expressed as mg\% using the formula:

$$
\begin{aligned}
& \text { Amino nitrogen }(\mathrm{mg} \%) \\
= & 0.0014 \times \mathrm{mL} \mathrm{NaOH} \times \mathrm{F}_{\mathrm{NaOH}} \times 100 / 10
\end{aligned}
$$

where $\mathrm{F}=0.1 \mathrm{~N} \mathrm{NaOH} /$ standardized $\mathrm{NaOH}$.

\subsubsection{Determination of Total Volatile Base \\ Nitrogen (TVB-N) and Histamine}

The TVB-N contents of the samples were determined by the Conway micro-diffusion method [10] while histamine was analyzed by the standard fluorometric method [11].

\subsection{Statistical Analyses}

Data were analyzed using Analysis of Variance (ANOVA) with three replications following the Complete Randomized Design. The Duncan's multiple range test was further used to determine the differences of means. In addition, pearson correlation and multiple linear regression analysis were carried out to determine the relationship and degree of influence between histamine values to other parameters such as salt content, temperature, $\mathrm{pH}$, amino nitrogen, TVB-N and microbial counts in fermented tuna viscera. Statistical analysis was performed using the Statistical Analysis System (SAS) program.

\section{Results and Discussion}

\subsection{Effect of Varying Salt Concentration on Mi- crobiological Changes of Tuna Viscera dur- ing Fermentation}

The changes in microbial flora of tuna viscera during fermentation are shown in Table 1. The total plate count (TPC) in all samples increased during the fermentation period however counts decreased with increasing salt concentration. Salt concentration affects the microbial count of microorganisms in the fermentation of tuna viscera $(p$ $<0.05$ ). Results further show that dayok produced from tuna viscera at $10 \%$ salt concentration had total plate count of $10^{7} \mathrm{cfu} / \mathrm{g}$ higher than the recommended value

Table 1. Microbial count $(\log \mathrm{CFU} / \mathrm{g})$ of fermented tuna viscera samples at varying temperature and salt concentration.

\begin{tabular}{ccccc}
\hline & \multicolumn{2}{c}{ TPC } & \multicolumn{2}{c}{ LAB } \\
\cline { 2 - 5 } Salt concentration & Initial & Final & Initial & Final \\
\cline { 2 - 5 } $10 \%$ & 4.54 & $7.47 \mathrm{a}$ & 3.48 & $6.80 \mathrm{a}$ \\
$17.5 \%$ & 4.00 & $4.87 \mathrm{~b}$ & 4.17 & $4.13 \mathrm{~b}$ \\
$25 \%$ & 4.00 & $5.00 \mathrm{~b}$ & 4.84 & $3.95 \mathrm{~b}$ \\
\hline
\end{tabular}

Means in the same column with different letter designation are significantly different from each other $(p<0.05)$. 
for total plate count of $10^{5} \mathrm{cfu} / \mathrm{g}(p<0.05)$ [12] and higher than those produced from samples at higher salt concentration with $10^{4}$ and $10^{5} \mathrm{cfu} / \mathrm{g}$ for $17.5 \%$ and $25 \%$ salt concentration, respectively. The presence of high viable count of aerobic microorganisms indicates that the product is prone to spoilage especially on tuna viscera fermented at $10 \% \mathrm{NaCl}$. According to Sanchez (2008) bacteria isolated from the intestines of marine fishes are halophilic and these microorganisms can also be introduced in the addition of salt. The principal halophilic species isolated from solar salt are Bacillus and Micrococcus, and Micrococcus in rock salt [13].

In addition, lactic acid bacteria count in all samples decreases during fermentation. Salt concentration significantly affects $\mathrm{LAB}$ count. Tuna viscera fermented at $10 \%$ $\mathrm{NaCl}$ had significantly higher LAB count of $10^{6} \mathrm{cfu} / \mathrm{g}$ compared to those fermented at $17.5 \%\left(10^{4} \mathrm{cfu} / \mathrm{g}\right)$ and $25 \% \mathrm{NaCl}\left(10^{3} \mathrm{cfu} / \mathrm{g}\right)$. This indicates that LAB present in the fermented product was able to grow at $10 \% \mathrm{NaCl}$ as reflected by its high viable count.

Generally, microbial counts decreased as salt concentration increased. The preservative action of salt is through osmotic pressure, it withdraws water from the tissue or microbial cells leading to microbial death.

\subsection{Effect of Varying Salt Concentration on Bi- ochemical Changes of Tuna Viscera during Fermentation}

Salt content. Salt content of tuna viscera increased during fermentation. Salt content of the fermented products with initial concentration of $10 \%, 17.5 \%$ and $25 \%$ increased to $19.20 \%, 29.76 \%$ and $31.39 \%$, respectively. Salt content values for samples fermented at $17.5 \%$ and $25 \%$ falls within the range from $17.5 \%$ to $35.4 \%$ as reported by Tsai et al. (2006) for commercial fish paste.

Sodium chloride plays an important role in microbial growth and therefore influences the activity of their amino acids decarboxylase [14]. High salt concentration also affects the growth of lactic acid bacteria since these type of bacteria are generally tolerant of moderate salt concentrations in the range of $10 \%$ to $18 \%$ [13].

pH and titratable acidity. Changes in $\mathrm{pH}$ values and titratable acidity during fermentation of tuna viscera are shown in Figure 1. The $\mathrm{pH}$ values of fermented tuna viscera with different salt concentrations slowly but continously decreased throughout the fermentation period with a corresponding increase in titratable acidity or lactic acid. At the end of the fermentation period, the initial $\mathrm{pH}$ of raw tuna viscera decreased from 6.13 to 5.61 . The $\mathrm{pH}$ values of the samples drop within the acceptable range of 5.4 - 6.2 on fermented fish products [13].

The $\mathrm{pH}$ of the samples decreases as salt concentration increases during the fermentation period. However, fermented tuna viscera at $17.5 \%$ and $25 \% \mathrm{NaCl}$ have com- parable $\mathrm{pH}$ values (5.33 and 5.32) and are significantly more acidic (2.84\% and 3.08\% lactic acid) than at $10 \%$ $\mathrm{NaCl}$ (pH 5.83 and $2.34 \%$ lactic acid). At increasing salt concentration, $\mathrm{pH}$ decreases or becomes acidic [15]. However, the final LAB count of samples at $17.5 \%$ and $25 \% \mathrm{NaCl}$ are lower than $10 \% \mathrm{NaCl}$ even though they are more acidic. This could be attributed to the formation of other acids (not lactic acid) during fermentation which affected the obtained values. Slow but gradual production of acid was observed throughout the fermentation period. This could be due to the presence of very little fermentable carbohydrate in the fish and the presence of a few numbers of lactic acid bacteria in fresh/raw material and in the fermenting fish during the early stages of fermentation.

Amino nitrogen. The amino nitrogen of dayok during fermentation at varying salt concentration ranged from $0.07 \%$ to $0.11 \%$. These values are within the reported data on fish sauce ranging from $0.07 \%$ to $1.43 \%$ [13]. An increase in amino nitrogen concentration is related to the degradation of the protein to amino acids released during hydrolysis. The quantity of amino acids formed went up with increasing time and salt concentration as shown in Figure 2.

Higher amino nitrogen are formed at $10 \% \mathrm{NaCl}$ compared to $17.5 \%$ and $25 \% \mathrm{NaCl}$ of which the latter values are relatively similar $(p<0.05)$. This indicates that microorganisms present in the mixture are able to degrade protein at $10 \% \mathrm{NaCl}$ which can be classified as moderately halophilic bacteria. According to Dissapharong et al.
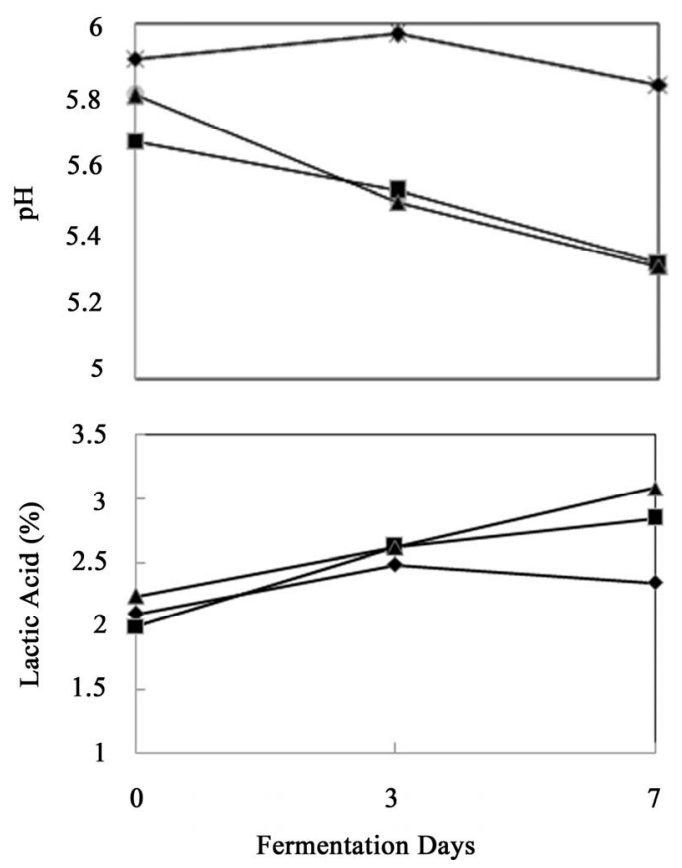

Figure 1. Changes in $\mathrm{pH}$ and lactic acid (\%) during fermentation of tuna viscera at $(\diamond) 10 \%$, (ש) $17.5 \%$ and $(\Delta)$ $\mathbf{2 5 \%}$ salt concentration. 


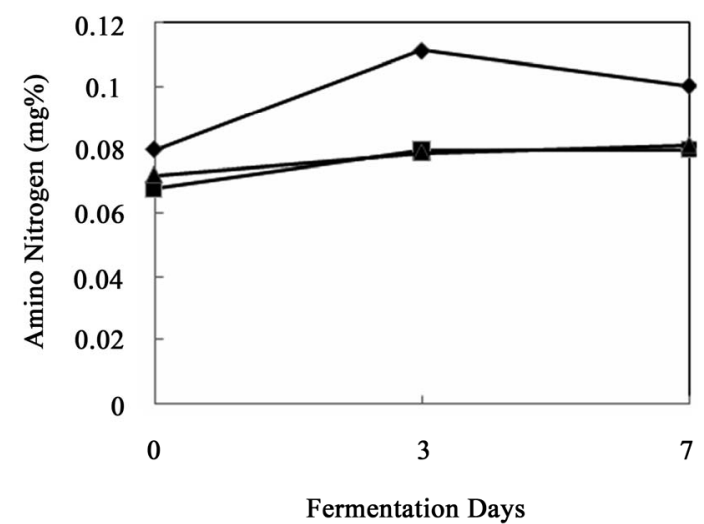

Figure 2. Changes in amino-nitrogen (mg\%) during fermentation of tuna viscera at $(\diamond) 10 \%,(\square) 17.5 \%$ and $(\Delta)$ $25 \%$ salt concentration.

(2006) the increase in nitrogenous basic compounds are caused by microbial proteolytic enzymes and consequently the utilization of amino acids by fermenting microorganisms. During storage, the protein breakdown products, peptides and amino acids, represent precursors for amine formation used by spoilage microorganisms.

Total volatile base nitrogen (TVB-N). Changes in TVB-N during fermentation of tuna viscera are shown in Figure 3. The measurement of TVB-N indicates the degree of proteolysis of samples caused by spoilage bacteria, autolytic enzymes, deamination of amino acids and nucleotide catabolites [3]. The TVB-N values of tuna viscera at $10 \%, 17.5 \%$ and $25 \% \mathrm{NaCl}$ are $226.80,81.60$ and $76.41 \mathrm{mg} / 100 \mathrm{~g}$, respectively. The TVB-N content of all samples except those fermented with $10 \% \mathrm{NaCl}(226.80$ $\mathrm{mg} / 100 \mathrm{~g}$ ) are within the limits set for dried and salted fish at 100 to $200 \mathrm{mg} / 100 \mathrm{~g}$ fish [16].

TVB-N content increases as salt concentration decreases $(p<0.05)$. The increase in TVB-N was due to the presence of higher number of microorganisms present in $10 \% \mathrm{NaCl}$ as compared to $17.5 \%$ and $25 \% \mathrm{NaCl}$. At salt concentrations higher than 10\%, TVB-N values are lower which could be attributed to the preservative action of salt. Similar results was observed by Tsai et al. (2006) who reported that the increase in TVB-N value in fermented fish products during fermentation was due to bacterial and enzymatic actions, particularly of the halophilic bacteria.

Generally, TVB-N values increases during fermentation of tuna viscera. The increase in TVB-N content over the fermentation period reflects the deterioration of the samples which is significantly affected by salt concentration.

\subsection{Effect of Varying Salt Concentration on Histamine Formation during Tuna Viscera Fermentation}

Salt concentration significantly influences histamine for-

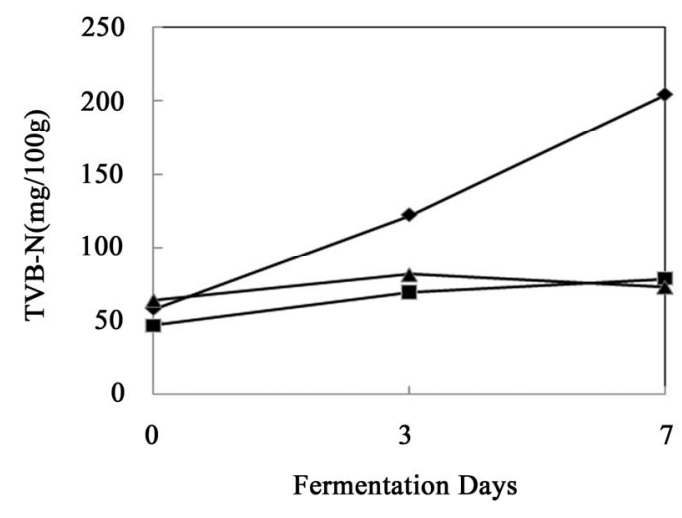

Figure 3. Changes in TVB-N (mg/100g) during fermentation of tuna viscera at $(\diamond) 10 \%,(\square) 17.5 \%$ and $(\Delta) 25 \%$ salt concentration.

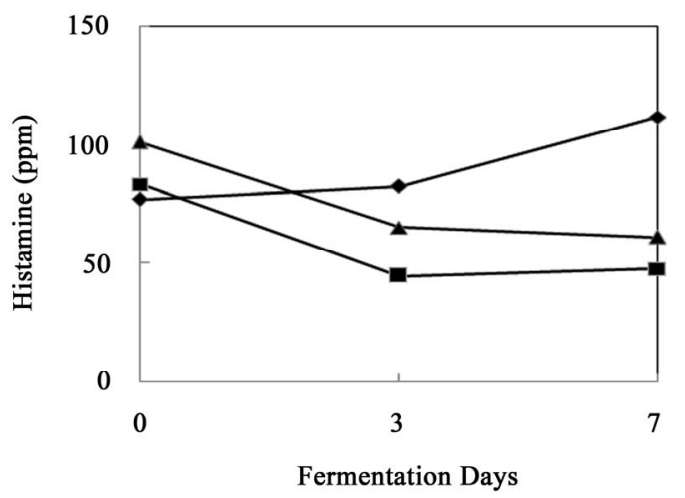

Figure 4. Changes in histamine (ppm) level during dayok fermentation at $10 \%(\diamond), 17.5 \%(\square)$ and $25 \%(\Delta)$ salt concentration.

mation due to its effect on the activity of histidine decarboxylase which is responsible for the conversion of histidine to histamine $(p<0.05)$. At a given salt concentration, histamine formation increases as salt content decreases (Figure 4). This indicates that high concentration of salt $\geq 17.5 \%-25 \%$ retards microbial histidine decarboxylase activity. This phenomenon can be attributed to reduce microbial cell activity due to the presence of high sodium chloride concentration causing withdrawal of water and other soluble contents from the cell through osmosis thus retarding or inhibiting their growth [14].

\subsection{Influence of Fermentation Parameters to Histamine Formation during Tuna Viscera Fermentation}

Results revealed that histamine content in fresh raw tuna viscera (49.60 ppm) was not significantly correlated to its initial total plate count. This was attributed to the immediate washing and icing of the raw material during transport which might inhibit or control the growth of histamine producing bacteria even though the histamine level is close to the FDA standard limit of safety ( $50 \mathrm{ppm})$. 
However, as fermentation progresses, histamine formation in tuna viscera is significantly affected by $\mathrm{pH}$, salt content, amino nitrogen, TVB-N and bacterial count (TPC and LAB). Significant linear relationship was observed among samples at different salt concentration and fermentation parameters on the formation of histamine in fermented tuna viscera. An increase in histamine content is affected by an increase in $\mathrm{pH}$, amino nitrogen, TVB-N, total plate count, LAB count and a decrease in salt content and lactic acid.

At low salt concentration, more histamine are formed compared to those fermented at salt concentrations higher than $10 \%$ with corresponding higher values in total plate count, LAB count, amino nitrogen, TVB-N at higher $\mathrm{pH}$ (less acidic environment).

Kimura et al. (2001) and Satomi et al. (2008) were able to observe histidine decarboxylase enzyme in halophilic lactic acid bacteria Tetragenococcus muriaticus [17] and Tetragenococcus halophilus [18] isolated from fish sauce. Furthermore, the histamine level of samples fermented at $17.5 \%$ and $25 \% \mathrm{NaCl}$ with values of 44.2 and $62.0 \mathrm{ppm}$, respectively showed no significant difference on $\mathrm{pH}$, TPC and LAB count.

Tuna viscera fermented at $10 \%$ and $25 \%$ salt concentrations have higher histamine values higher than the standard limit of safety at $50 \mathrm{ppm}$. On the other hand, histamine content of samples fermented at $17.5 \%$ salt concentration was below the food safety limit. The findings of the study suggest that tuna viscera fermented at low salt concentrations (10\%) have higher histamine formation in tuna viscera than at higher salt concentration of $17.5 \%$.

\section{Conclusion}

The formation of histamine is significantly influenced by salt concentration. As salt content decreases histamine content increases. Low salt concentration at $10 \% \mathrm{NaCl}$ boasted histamine levels higher than the FDA safety limit. Therefore, the amount of salt to be added for dayok fermentation can be lowered from $25 \%$ (usual practice) to $17 \%$ to reduce histamine formation.

\section{Acknowledgements}

This research was financially supported by the Southeast Asian Regional Center for Graduate Study and Research in Agriculture (SEARCA) and the Commission on Higher Education (CHED) Higher Education Development Program, Philippines.

\section{REFERENCES}

[1] Y. H. Tsai, C. Y. Lin, L. T. Chien, T. M. Lee, C. I. Wei and D. F. Hwang, "Histamine Contents of Fermented Fish Products in Taiwan and Isolation of Histamine-Forming
Bacteria,” Food Chemistry, Vol. 98, No. 1, 2006, pp. 6470. doi:10.1016/j.foodchem.2005.04.036

[2] L. Lehane and J. Olley, "Histamine Fish Poisoning Revisited," International Journal of Food Microbiology, Vol. 58, No. 1-2, 2000, pp. 1-37. doi:10.1016/S0168-1605(00)00296-8

[3] FDA, "Fish and Fishery Products Hazards and Controls Guidance,” Scombrotoxin (Histamine Formation), 3rd Edition, 2001. http://www.cfsan.fda.gov/ comm/haccp4g.html

[4] S. L. Taylor, "Histamine Food Poisoning: Toxicology and Clinical Aspects," Critical Reviews in Toxicology, Vol. 17, No. 2, 1986, pp. 91-117. doi:10.3109/10408448609023767

[5] S. Brillantes, S. Paknoi and A. Totakien, "Histamine Formation in Fish Sauce Production,” Journal of Food Science, Vol. 67, No. 6, 2002, pp. 2090-2094. doi:10.1111/j.1365-2621.2002.tb09506.X

[6] Ma. L. N. Dapkevicius, M. J. R. Nout, F. M. Rombouts, J. H. Houben and W. Wymenga, "Biogenic Amine Formation and Degradation by Potential Fish Silage Starter Microorganisms," International Journal of Food Microbiology, Vol. 57, No. 1-2, 2000, pp. 107-114. doi:10.1016/S0168-1605(00)00238-5

[7] S. Dissaraphong, S. Benjakul, W. Visessanguan and H. Kishimura, "The Influence of Storage Conditions of Tuna Viscera Before Fermentation on the Chemical, Physical and Microbiological Changes in Fish Sauce during Fermentation," Bioresource Technology, Vol. 97, No. 16, 2006, pp. 2032-2040. doi:10.1016/j.biortech.2005.10.007

[8] H. Yongjin, X. Wensyongjin and L. Xiaoyong, “Changes in Biogenic Amines in Fermented Silver Carp Sausages Inoculated with Mixed Starter Cultures," Food Chemistry, Vol. 104, No. 1, 2007, pp. 188-195. doi:10.1016/j.foodchem.2006.11.023

[9] T. Kuda, T. Mihara and T. Yano, "Detection of Histamine and Histamine-Related Bacteria in Fish-Nukazuke, a Salted and Fermented Fish with Rice-Bran, By Simple Colorimetric Microplate Assay,” Food Control, Vol. 18, No. 6, 2007, pp. 677-681.

doi:10.1016/j.foodcont.2006.02.016

[10] F. Cobb, I. Alanez and C. Thompson, "Biochemical and Microbial Studies on Shrimp: Volatile Nitrogen and Amine Nitrogen Analysis,” Journal of Food Science, Vol. 38, No. 3, 1973, pp. 431-436. doi:10.1111/j.1365-2621.1973.tb01447.x

[11] AOAC, "Methods of Analysis," 15th Edition, Association of Official Analytical Chemists, Washington DC, 1990.

[12] International Commission on Microbiological Specifications for Foods, ICMSF, "Microorganisms in Foods 2, Sampling for Microbiological Analysis: Principles and Specific Application,” 2nd Edition, University of Toronto Press, Buffalo, 1986.

[13] P. C. Sanchez, "Philippine Fermented Foods. Principle and Technology,” The University of the Philippines Press, Quezon City, 2008.

[14] M. Z. Zaman, A. S. Abdulamir, F. A. Bakar, J. Selamat and J. Bakar, "A Review: Microbiological, Physicoche- 
mical and Health Impact of High Level of Biogenic Amines in Fish Sauce,” American Journal of Applied Sciences, Vol. 6, No. 6, 2009, pp. 1199-1211. doi:10.3844/ajassp.2009.1199.1211

[15] C. Paludan-Muller, M. Madsen, P. Sophanodora, L. Gram and P. L. Muller, "Fermentation and Microflora of Plaasom, a Thai Fermented Fish Product Prepared with Different Salt Concentrations," International Journal of Food Microbiology, Vol. 73, No. 1, 2002, pp. 61-70. doi:10.1016/S0168-1605(01)00688-2

[16] J. J. Connell, “Control of Fish Quality,” 3rd Edition, Fishing New Books, Oxford, 1990.
[17] B. Kimura, Y. Konagaya and T, Fujii, "Histamine Formation by Tetragenococcus muriaticus, a Halophilic Lactic Acid Bacterium Isolated from Fish Sauce,” International Journal of Food Microbiology, Vol. 70, No. 1-2, 2001, pp. 71-77.

[18] M. Satomi, M. Furushita, H. Oikawa, M. Y. Takahashi and Y. Yano, "Analysis of A $30 \mathrm{Kbp}$ Plasmid Encoding Histidine Decarboxylase Gene in Tetragenococcus halophilus Isolated from Fish Sauce,” International Journal of Food Microbiology, Vol. 126, No. 1-2, 2008, pp. 202-209. doi:10.1016/j.ijfoodmicro.2008.05.025 